\section{Comparison of wound healing time post odontectomy surgery using silk and catgut sutures in Pirngadi Hospital}

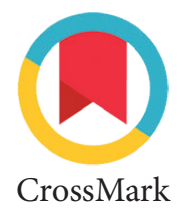

Department of Oral and Maxillofacial Surgery, Faculty of Dentistry, Universitas Sumatera Utara, Medan, Indonesia
*Correspondence to: Rahmi Syaflida, Department of Oral and Maxillofacial Surgery, Faculty of Dentistry, Universitas Sumatera Utara, Medan, Indonesia rahmi.syaflida@gmail.com

Received: 13 September 2018 Revised: 18 February 2019 Accepted: 7 March 2019 Available Online 1 April 2019

\section{Introduction}

An Impacted tooth is a tooth that are not perfectly erupted or erupted partially with positions that are not well supported by other tooth, bones, and soft tissues. This situation can occur due to insufficient eruption space, obstruction of neighboring tooth, and abnormal eruption path. A fully or partially impacted tooth must be removed when signs of pathological changes are found..$^{1-3}$

Odontectomy is a minor surgery to remove impacted teeth that leave a surgical wound. Suturing of the surgical wound is necessary, aiming at holding a flap over the wound, reapproximating the wound edges, protecting underlying tissues from infection or other irritating factors, and preventing postoperative hemorrhage. ${ }^{3}$ Surgical wound healing may be delayed in the absence of the typical clinical features of infection. ${ }^{4}$ Banche's researchin comparison of silk, nylon, polyester, and polyglecaprone 25 in dentoalveolar surgery showed that there were more bacteria in non-absorbable sutures than absorbable sutures. ${ }^{5}$ Selvig's research on silk and chromic gut showed that bacterial invasion of the suture track was a common outcome regardless of the material used, but it was particularly prominent for silk sutures. ${ }^{6}$ Lilly's research on multifilament and monofilament sutures showed that the multifilament suture materials (silk, cotton, polyester and linen) resulted in a significantly higher tissue reaction as compared to
Results: The results were statistically analyzed using Mann-Whitney Test. There was no significant relationship $(p>0.05)$ between the wound healing time to the suture type on the first day post odontectomy. On the seventh day, it was found that there was a significant relationship ( $p$ $<0.05$ ) which silk had a score of $1.40 \pm 0.507$ while catgut had a score of $1.07 \pm 0.258$.

Conclusion: Catgut has a better wound healing time than silk.

Keywords: Catgut, Odontectomy, Silk, Wound Healing

Cite This Article: Syaflida R, Rusdy H, Riza A, Sitorus M. 2019. Comparison of wound healing time post odontectomy surgery using silk and catgut sutures in Pirngadi Hospital. Journal of Dentomaxillofacial Science 4(1): 32-35. D0l: 10.15562/jdmfs.v4i1.804

the monofilament (steel, nylon, surgical gut, and chromic gut) suture materials. ${ }^{7}$ Despite of these studies, the best sutures material for wound healing has not been concluded by the researchers. The present study aimed to compare post-odontectomy wound healing time using silk and catgut at Pirngadi General Hospital from May to June 2018.

\section{Material and Methods}

This study was an experimental study with post-test only design. Wound healing score as independent variable was obtained by conducting examination on day 1 and day 7 after the extraction of the tooth. Subject included in this study were patient with third molar impaction from 20 to 45 years old at Pirngadi General Hospital from May to June 2018. The number of patients studied was 30 people in which 15 people used silk and 15 people used catgut. Every patient was given an informed consent about the procedures of this research and asked about the willingness to participate in this study. Study was conducted after obtaining Ethical Clerance No: 185/TGL/KEPK FK USU-RSUP HAM/2018 from Health Research Ethical Committee, Faculty of Medicine, Universitas Sumatera Utara.

Wound healing scores was assessed on the first and seventh days post odotectomy by seeing signs of inflammation. Each sign of inflammation obtained 
Table $1 \quad$ Results on day 1

\begin{tabular}{lcccccccc}
\hline & \multicolumn{9}{c}{ Wound Healing Score Day $\mathbf{1}$} & \multicolumn{2}{c}{ Total } \\
Suture type & \multicolumn{2}{c}{ Good } & \multicolumn{2}{c}{ Moderate } & \multicolumn{2}{c}{ Poor } & \multicolumn{2}{c}{ Tota } \\
& $\mathbf{n}$ & $\%$ & $\mathbf{n}$ & $\%$ & n & $\%$ & n & $\%$ \\
\hline Silk & 0 & 0 & 5 & 33.33 & 10 & 66.67 & 15 & 100 \\
Catgut & 0 & 0 & 1 & 6.67 & 14 & 93.33 & 15 & 100 \\
\hline
\end{tabular}

Table 2 Results on day 7

\begin{tabular}{lcccccccc}
\hline & \multicolumn{4}{c}{ Wound Healing Score Day 1 } & \multicolumn{2}{c}{ Total } \\
Suture type & \multicolumn{2}{c}{ Good } & \multicolumn{2}{c}{ Moderate } & \multicolumn{2}{c}{ Poor } & \multicolumn{2}{c}{ Tota } \\
& $\mathbf{n}$ & $\%$ & $\mathbf{n}$ & $\%$ & $\mathbf{n}$ & $\%$ & n & $\%$ \\
\hline Silk & 9 & 60 & 6 & 40 & 0 & 0 & 15 & 100 \\
Catgut & 14 & 93.33 & 1 & 6.67 & 0 & 0 & 15 & 100 \\
\hline
\end{tabular}

Table 3 Mean score on day 1

\begin{tabular}{lcccc}
\hline Suture type & Mean \pm SD & $\mathbf{n}$ & $\%$ & p-value \\
\hline Silk & $2.67 \pm 0.488$ & & & \\
Catgut & $2.93 \pm 0.258$ & 15 & 100 & 0.073 \\
\hline
\end{tabular}

\section{Table 4 Mean score on day 7}

\begin{tabular}{lcccc}
\hline Suture type & Mean \pm SD & $\mathbf{n}$ & $\%$ & p-value \\
\hline Silk & $1.40 \pm 0.507$ & 15 & 100 & 0.015 \\
Catgut & $1.07 \pm 0.258$ & & & \\
\hline
\end{tabular}
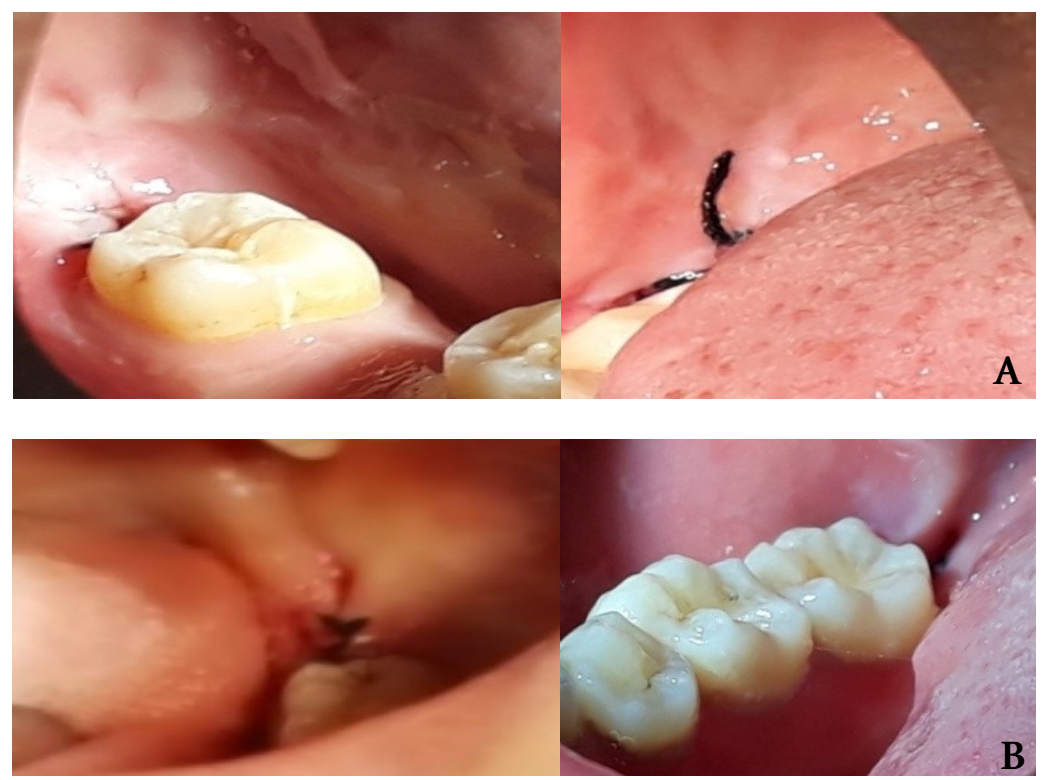

will be given a score of 1 so that the accumulation of scores becomes the researcher's assessment of the sutures under study. Scoring was done by calculating all sign of inflammation with higher scores indicating poorer wound healing. Healing status was graded by good (0-1), moderate (2), and poor $(>3)$.

All results are checked to ensure the assessment matches the score and criteria used. The end result of each inspection is calculated manually and the data is processed computerized. In the Saphiro-Wilk test, it was found that the data in this study were not normally distributed. Thus, the data analysis test used is the Mann-Whitney test.

\section{Results}

Figure $1 \mathrm{~A}$ and figure $1 \mathrm{~B}$ results on day 1 examination were $33.33 \%$ samples using silk had a moderate score and $66.67 \%$ samples had a poor score. Then $6.67 \%$ samples using catgut had a moderate score and 93.33\% samples had a poor score. There were no samples using silk or catgut which had a good score on the first day after odontectomy table 1.

Figure $2 \mathrm{~A}$ and figure $2 \mathrm{~B}$ result on day 7 exa-mination were $60 \%$ samples using silk had a good score and $40 \%$ samples had a poor score. Then $93.33 \%$ samples using catgut had a good score and $6.67 \%$ samples had a moderate score. There were no samples using silk or catgut which had a poor score on the seventh day after odontectomy table 2.

Based on day 1 results, it was found that the mean score of wound healing time in the samples using silk was $2.67 \pm 0.488$ and the mean score of wound healing time on the samples using catgut was $2.93 \pm 0.258$ with a p-value of 0.073 . Thus it can be concluded that there is no significant relationship between wound healing time and suture type on the first day after odontectomy table 3 .

Based on day 7 results, the mean score of wound healing time on the sample using silk was $1.40 \pm 0.507$ and the mean score of wound healing time in the sample using catgut was $1.07 \pm 0.258$ with a pvalue of 0.015 . Thus it can be concluded that there is a significant relationship between the time of wound healing and suture type on the seventh day post odontectomy table 4 .

\section{Discussion}

According to Chu, biocompatibility of a suture is the differentiator of each suture in influencing the -

Figure 1 Result on day 1, A. Silk Sutures, B. Catgut Sutures 

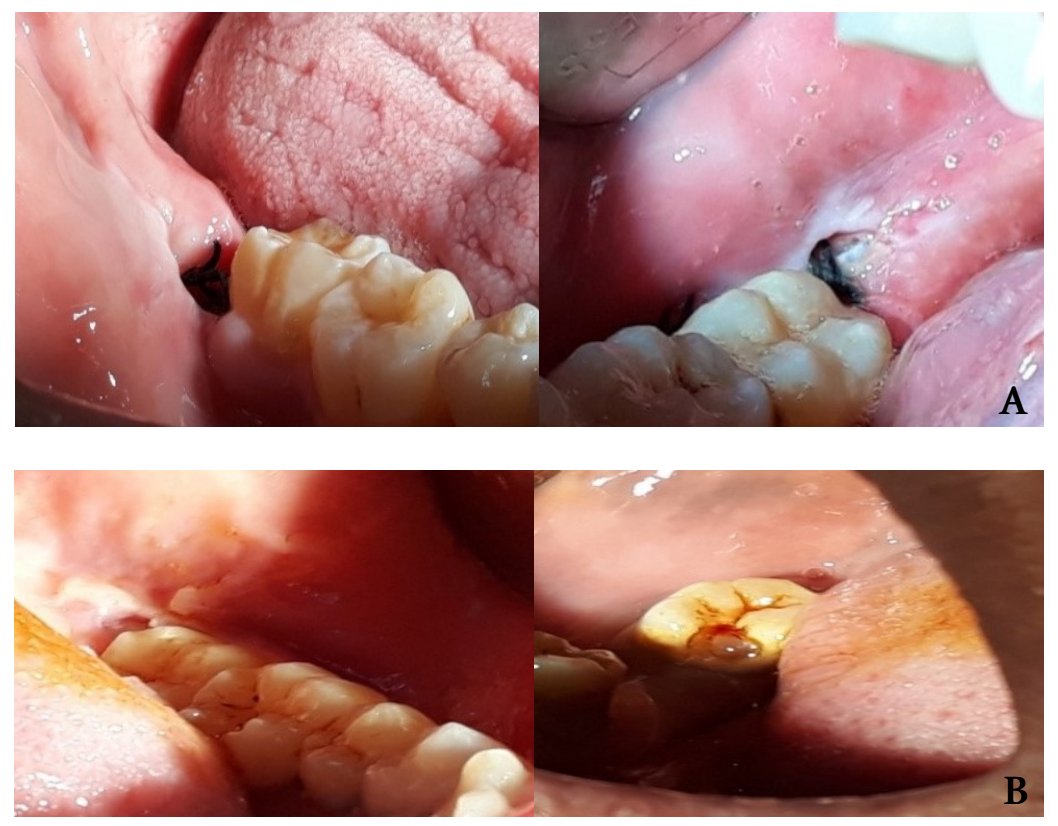

Figure 2 Result on day 7, A. Silk Sutures, B. Catgut Sutures

surrounding tissue. Rigid threads will have stiffness on the cut edge. The stiff end of the suture can cause mechanical irritation to the surrounding tissue causing an inflammatory response. This is often found in monofilament suture and is never found in multifilament suture. ${ }^{8}$

Selvig et al. $^{6}$ study of mucosal inflammatory responses to silk, catgut, e-PTFE and poliglactin 910 showed that the inflammatory response due to suturing trauma. The differences in the four sutures by comparing the fluid response of exudates, the cellular intrusion zone, and the presence of inflammatory cells in the vicinity of the wound histologically. On the third day, the inflammatory response encountered in all four sutures did not show significant results. ${ }^{6,7}$

Chu et al. $^{8}$ and Selvig et al. ${ }^{6}$ opinion is in accordance with the research that has been done which catgut has an average score of wound healing time that is worse than silk on the first day after odontectomy. In this study, there was no significant difference $(p>0.05)$ between the mean score of wound healing in samples of silk and catgut. Catgut is a monofilament type suture so it has a rigid nature. The stiffness of catgut causes irritation to the oral tissues, causing an inflammatory response that is worse than silk on the first day after odontectomy. ${ }^{6-8}$

Another factor that might trigger tissue reactions is the response of bacteria to the surgical thread. Katz et al. ${ }^{9}$ investigated bacterial adhesion to surgical sutures (bacteria adherence).
The results showed that bacteria in silk sutures had five to eight times more bacteria than nylon with the least number of bacteria. ${ }^{11}$ In another study, Banche et al. ${ }^{5}$ Studied microbial colonization in various intraoral sutures from patients after dentoalveolar surgery. The results showed a greater number of bacteria in silk sutures compared to polyglecaprone $25.7,9$

The presence of sutures in tissues can increase the risk of infection, especially in multifilament. When the sutures penetrates the mucosa, the oral fluid that acts as a bacterial medium will enter the gap between the filaments causing the spread of bacteria to the surrounding tissue. The spread of these bacteria can trigger a wider inflammatory reaction, especially around the tissues with multifilament sutures. ${ }^{8}$ That multifilament sutures provide an inflammatory response that is worse than monofilament sutures. 7,10 The research that has been done where the silk sutures was significantly $(\mathrm{p}<0.05)$ had an average score of wound healing time that was worse than catgut on the seventh day post odontectomy. ${ }^{7,10}$

\section{Conclusion}

Based on the results of research and data analysis, it can be concluded that catgut sutures have better wound healing time on the seventh day after odontectomy. The catgut sutures have a mean score of wound healing time that is better than silk sutures. However, catgut sutures have rigid nature so it tends to give trauma to the oral mucosa tissue early after surgery and is more difficult to make knot than silk thread so that the time needed to perform suturing procedures tends to be long and the risk of trauma and irritation in the patient's oral cavity is quite large. Silk sutures has better biocompatibility than catgut so that patients feel more comfortable when suturing procedures with silk suture.

\section{Aknowlegdment}

The authors would like to thank the patients who have been willing to share his case for reported and participated cooperatively in this study.

\section{Conflict of Interest}

The authors report no conflict of interest.

\section{References}

1. Rentont T. Surgical management of third molars. In: Andersson L, Kahnberg KE, Pogrel MA. eds. Oral and maxillofacial surgery, Oxford: Blackwell Publishing Ltd; 2010. p. 219-258. 
2. Juodzbalys G. Daugela P. Mandibular third molar impaction: review of literarature and a proposal of a classification. J Oral Maxillofac Res 2013;4: 1-12.

3. Saleh E. Strategies in reducing odontectomy complication. J Mutiara Medika 2006;6: 122-125.

4. Edwards R, Harding K. Bacteria and wound healing. Curr Opin Infect Dis 2004;17: 91-96.

5. Banche G, Roana J, Mandras N et al., Microbial adherence on various intraoral suture materials in patients undergoing dental surgery. J Oral Maxillofac Surg 2007;65: 1503-1507.

6. Selvig KA, Biagiotti GR, Leknes KN, et al. Oral tissue reactions to suture materials Int J Periodont Res Dent 1998; 18: 475-487.

7. Javed F, Al-Askar M, Almas K, et al. Tissue reactions to various suture materials used in oral surgical interventions. Int Scholarly Res Network Dent 2012: 1-6.
8. Chellamani KP, Veerasubramanian D, Balaji RSV. Surgical sutures: an overview. J Acad Indus Res 2013;1: 778-782.

9. Katz S, Izhar M, Mirelman D. Bacterial adherence to surgical sutures: a possible factor in suture induced infection. Ann Surg 1981;194: 35-41.

10. Leknes KN, Røynstrand IT, Selvig KA. Human gingival tissue reactions to silk and expanded polytetrafluoroethylene sutures. J Periodontol 2005;76: 34-42.

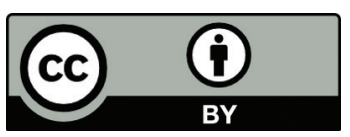

This work is licensed under a Creative Commons Attribution 